
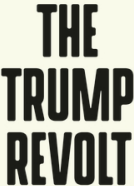

9781526153685

๑23 01: 06:42PM

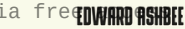


The Trump revolt

\section{MANCHESTER 1824}

Manchester University Press

Edward Ashbee - 9781526153685 


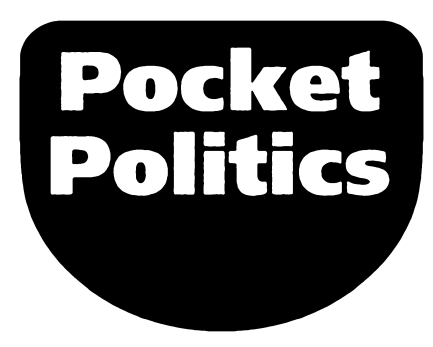

\section{POCKET POLITICS}

\section{SERIES EDITOR: BILL JONES}

Pocket politics presents short, pithy summaries of complex topics on socio-political issues both in Britain and overseas. Academically sound, accessible and aimed at the interested general reader, the series will address a subject range including political ideas, economics, society, the machinery of government and international issues. Unusually, perhaps, authors are encouraged, should they choose, to offer their own conclusions rather than strive for mere academic objectivity. The series will provide stimulating intellectual access to the problems of the modern world in a user-friendly format.

\section{Previously published}

Reform of the House of Lords Philip Norton 


\title{
The Trump revolt
}

\author{
Edward Ashbee
}

Manchester University Press 
Copyright (C) Edward Ashbee 2017

The right of Edward Ashbee to be identified as the author of this work has been asserted by him in accordance with the Copyright, Designs and Patents Act 1988

Published by Manchester University Press

Altrincham Street, Manchester M1 7JA

www.manchesteruniversitypress.co.uk

British Library Cataloguing-in-Publication Data

A catalogue record for this book is available from the British Library

ISBN 9781526122988 paperback

First published 2017

The publisher has no responsibility for the persistence or accuracy of URLs for any external or third-party internet websites referred to in this book, and does not guarantee that any content on such websites is, or will remain, accurate or appropriate

Typeset

by Toppan Best-set Premedia Limited

Printed in Great Britain

by Lightning Source 